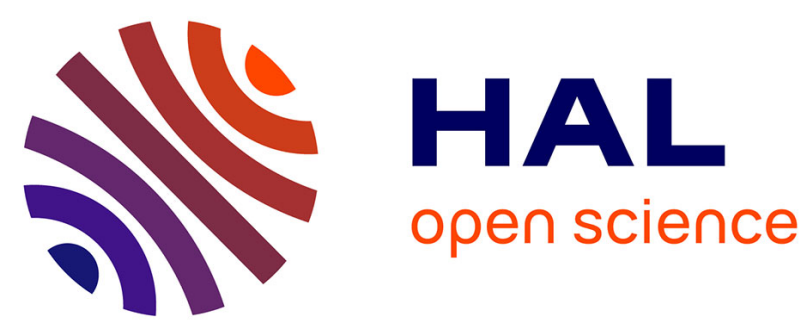

\title{
Phase Noise Reduction of Narrow Linewidth Optical Fibre-Ring Based Microwave Oscillators: Modelling and Experimental Results
}

Aude Bouchier, Khaldoun Saleh, Pierre-Henri Merrer, Olivier Llopis

\section{- To cite this version:}

Aude Bouchier, Khaldoun Saleh, Pierre-Henri Merrer, Olivier Llopis. Phase Noise Reduction of Narrow Linewidth Optical Fibre-Ring Based Microwave Oscillators: Modelling and Experimental Results. Conference on Lasers and Electro-Optics (CLEO Europe), May 2011, Munich, Germany. 1 page. hal00597358

\section{HAL Id: hal-00597358 \\ https://hal.science/hal-00597358}

Submitted on 31 May 2011

HAL is a multi-disciplinary open access archive for the deposit and dissemination of scientific research documents, whether they are published or not. The documents may come from teaching and research institutions in France or abroad, or from public or private research centers.
L'archive ouverte pluridisciplinaire HAL, est destinée au dépôt et à la diffusion de documents scientifiques de niveau recherche, publiés ou non, émanant des établissements d'enseignement et de recherche français ou étrangers, des laboratoires publics ou privés. 


\title{
Phase Noise Reduction of Narrow Linewidth Optical Fibre-Ring Based Microwave Oscillators : Modelling and Experimental Results
}

\author{
A. Bouchier ${ }^{1,2}$, K. Saleh ${ }^{1,2}$, P.-H. Merrer ${ }^{1,2}$ and O. Llopis ${ }^{1,2}$ \\ 1. CNRS ; LAAS ; 7 avenue du colonel Roche, F-31077 Toulouse Cedex 4, France \\ 2. Université de Toulouse ; UPS, INSA, INP, ISAE; UT1, UTM, LAAS ; F-31077 Toulouse Cedex 4, France
}

The utilisation of optical carriers is of strong interest for microwave applications such as microwave generation [1]. For example, optical resonators can replace microwave resonators and allow to overcome the performance of traditional microwave oscillators in terms of compactness and quality factor, which will strongly reduce the phase noise of the overall microwave oscillator. Whispering gallery modes resonators have been studied and used in this aim [2,3]. Whereas they exhibit very interesting characteristics in terms of quality factor, the long-term stability of the resulting microwave oscillator is reduced because of the mechanical instability induced by the fibre-to-resonator coupling systems. An interesting alternative consists in using optical fibres based ring resonators [4]. This kind of set-up presents easily a high stability in time in terms of light coupling, while having great potential for exhibiting high-Q values. It is composed of a single-mode fibre with a length between 10 and $20 \mathrm{~m}$, and two low losses fibered couplers. The choice of the fibre length and the couplers ratios are critical for the optical quality factor of the resonator. A first study of an optoelectronic oscillator (OEO) based on this fibre ring (Fig. 1) has shown that, despite a very high Q-factor of the resonator (about $2.10^{8}$ at $1.55 \mu \mathrm{m}$ for a length of $10 \mathrm{~m}$ ), the phase noise of the OEO can be high (Fig. 2) and has to be decreased [4]. We have thus based our optimisation of resonant fibre rings on a theoretical study of the OEO phase noise to understand the influence of the resonator on the noise of the oscillator. This study concerns mainly the phase noise due to the white frequency noise induced by our resonators and is comparable to the one proposed for purely microwave oscillators by J. Everard [5].

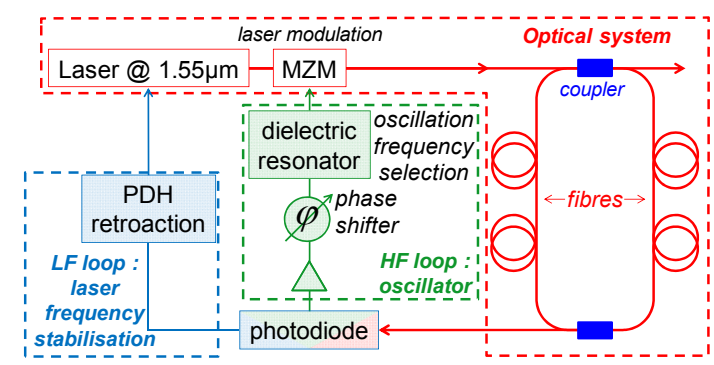

Fig. 1 Set-up of the OEO.

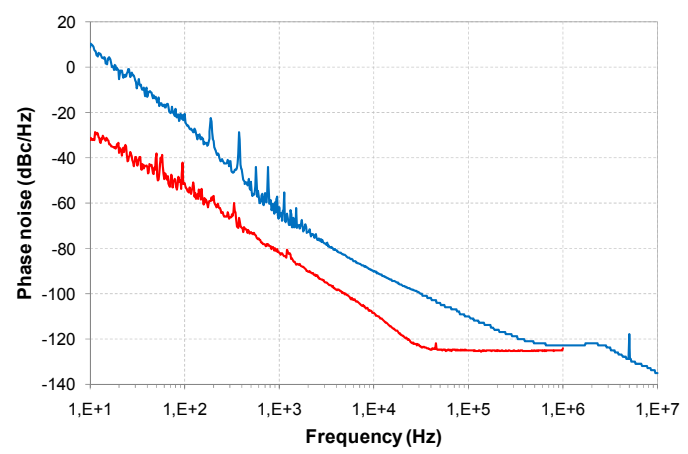

Fig. 2 Phase noise of the OEO with the non optimized fibre ring (in blue) and with the optimized fibre ring (in red).

Comparisons between modelling and experiments, performed on both the resonator and oscillator noise, have allowed us to determine with accuracy the physical parameters of our first fibre ring, mainly the transmission and losses of its couplers and the intrinsic losses of the ring. An in-depth study of the influence of the couplers and ring losses on the noise performance allowed to conclude that the best performance in terms of optical quality factor does not lead automatically to the lowest phase noise. A global optimum has thus to be found. In the frame of this work, we thus have proposed a new resonant fibre ring design thanks to this analysis. Its quality factor is $5.10^{9}$ at $1.55 \mu \mathrm{m}$, for a length of $20 \mathrm{~m}$. We have thus built a new OEO with it. Its phase noise has considerably been improved (Fig. 2). We can observe on this spectrum that the main component of the OEO phase noise is the flicker-like noise. The next step of this study is to understand the origin of this noise in this case and how to reduce it.

\section{References}

[1] L. Maleki, S. Yao, Y. Ji, and V. Ilchenko, "New schemes for improved opto-electronic oscillator," in Proc. of IEEE International Topical Meeting on Microwave Photonics, 177 (1999).

[2] M. Gorodetsky, A. Savchenkov and S. Ilchenko, "Ultimate Q of optical microsphere resonator," Opt. Lett. 21, 453 (1996).

[3] D. Armani, T. Kippenberg, S. Spillane and K. Vahala, "Ultrahigh-Q toroid microcavity on a chip," Nature 421, 925 (2003).

[4] P.H. Merrer, A. Bouchier, H. Brahimi, O. Llopis and G. Cibiel,"High-Q optical resonators for stabilization of high spectral purity microwave oscillators," in Proc. of IEEE European Frequency and Time Forum -International Frequency Control Symposium, 866 (2009).

[5] J. Everard, "Low noise oscillators," in Microwave Symposium Digest (IEEE MTT-S International, 1992) 2, 1077. 